\title{
Studies on Developing Adipose Tissue: Lipolytic Activity in Human Fetal Subcutaneous Tissue as an Indication of Adipose Potential
}

\author{
MARJORIE DUNLOP AND JOHN M. COURT ${ }^{29)}$ \\ Department of Paediatrics, University of Melbourne, and Royal Children's Hospital, Melbourne, Australia
}

\begin{abstract}
Summary
In a previous study of children in the first 2 years of life in which all cells in adipose tissue were examined, we found numbers of small cells which do not contain the extensive intracellular triglyceride deposits characteristic of the mature fat cell. Similar cells have also been detected in fetal subcutaneous tissue. It seems important to establish whether the cells of fetal subcutaneous origin are adipocyte precursors. Isolated adipose cells and homogenates of isolated cells can be expected to show hormone-sensitive lipase activity. This paper reports studies on the lipolytic activity of fetal subcutaneous tissue cells. Fetal subcutaneous tissue, obtained after therapeutic abortion, was dissected from the abdominal wall. To provide a substrate for lipolytic activity in fetal tissue where little intracellular triglyceride is present, triolein as glycerol trioleate was added to the incubations. Additions of either heparin or epinephrine were made at timed intervals. Levels of cAMP were determined in homogenates of tissue after epinephrine stimulation without added triglyceride. Accumulation of tissue triglyceride starts at 16-17 weeks and increases through the ages studied. After the addition of epinephrine $\left(10^{-4} \mathrm{M}\right)$ there is substantial release of free fatty acid (FFA) with all tissue homogenates. The addition of epinephrine to the preparation in which no exogenous triglyceride substrate had been added, was associated with a rise in cAMP. Glycerol release was also detected at this time. A dose relationship for cAMP production after epinephrine is present at each age studied. Changing levels in CAMP in fetal tissue with epinephrine suggests an activity similar to the mature adipose cell membrane. These findings do not necessarily indicate an in vivo process occurring at this period of development but rather show a functional ability of the cell. When considering this potential in a cell taken from a site where adult subcutaneous adipose deposition occurs, the definition of an adipose cell should not rely entirely on the presence of accumulated triglyceride.
\end{abstract}

\section{Speculation}

The recognition of fetal tissue with the lipolytic characteristics of mature fat tissue suggests that in fetal life, this tissue may be responsive to changes in the fetal environment. The nutritional and hormonal environment of the fetus may thus influence the development of adipose stores.

There has been considerable importance placed on the significance of numbers of cells in developing adipose tissue. Obese children have increased numbers of fat cells in their adipose tissue and there have been several studies defining the age when fat cell replication can occur. Brook et al. (2) have reported that fat cells increase in number in the fetus from 30 weeks of gestation. Hirsch and Knittle (14) have shown that hyperplasia in adipose tissue may occur to 13 years of age. In these studies only mature adipocytes were studied, as identification of cells has depended on the presence of accumulated triglyceride within the cell. Adipocytes may only undergo replication before they accumulate triglyceride as no further division is thought to occur once the cell contains fat (12). Thus the reports of critical times for fat cells replication are not based on observations made on dividing fat cells and may not reflect the actual time of adipose cell replication.

In a previous study of children in the first 2 years of life, in which all cells in adipose tissue were examined, we have found numbers of small cells which do not contain the extensive intracellular triglyceride deposits characteristic of the mature fat cell (1). Similar cells have also been detected in fetal subcutaneous tissue from gestational age 16 weeks. It was not possible in that study to establish morphologically whether these cells were precursors to fat cells, although their presence in abundance in fetal subcutaneous and in infant adipose tissue has led us to believe that they may be so. It would seem important to establish whether the cells or fetal subcutaneous origin are in fact adipocyte precursors, and this has been attempted by investigating one of their metabolic characteristics, lipolytic ability.

Lipolytic activity in adipose tissue may be attributed to the action of intracellular triglyceride lipases and lipoprotein lipase $(17,19,27)$. Of the intracellular triglyceride lipase activities, hormone-sensitive triglyceride lipase has been demonstrated in rat and human adipose tissue $(11,21)$. The initial activation in the lipolytic response to hormones is that of adenyl cyclase at the cell membrane. This results in the activation of cAMP dependent protein kinase with subsequent activation of triglyceride lipase within the adipose cell $(5,16)$.

The extracellular lipoprotein lipase is found in human adipose tissue and is located in the capillary endothelium of the tissue $(8,24)$. This enzyme hydrolyses protein bound triglyceride and activation by heparin is a distinguishing feature of its activity ( 7 , $15)$.

Isolated adipose cells and homogenates of isolated cells can be expected to show hormone sensitive lipase activity, whereas total adipose tissue and its homogenates may in addition show heparin-activated lipase activity. This paper reports studies on the lipolytic activity of fetal subcutaneous tissue cells to establish their potential as adipocyte precursors.

\section{MATERIALS AND METHODS}

Fetal subcutaneous tissue, obtained after therapeutic abortion, was dissected from the abdominal wall in a region immediately above the entry of the umbilicus. This area is known to be one of adipose tissue deposition in the adult and was chosen to exclude any known area of brown fat accumulation in the fetus. Gestational age was from 10-22 weeks judged from maternal history and crown-rump measurements. Tissue was transported at room temperature and used immediately wher- 
ever possible. In studying fetal tissue in which triglyceride content is not constant and isolation of cells achieved only with difficulty, finely ground tissue was used throughout. Results were expressed per $\mathrm{g}$ tissue wet wt. Homogenates of fetal tissue were prepared at $4^{\circ}$ in Krebs-Ringer phosphate buffer at $\mathrm{pH} 7.4$ containing half the reported calcium concentration (22) by using a glass hand-held homogenizer.

\section{TRIGLYCERIDE CONTENT}

Triglyceride content was estimated as glyceride-glycerol (26) after Folch extraction (10). Triglyceride content was expressed as milligrams of triglyceride per tissue wet wt.

\section{HOMOGENATE LIPOLYTIC ABILITY}

To provide a substrate for lipolytic activity in fetal tissue where little intracellular triglyceride is present, triolein as glycerol trioleate (BDH Chemicals Ltd.) was added to the incubations. Triolein was purified by chromatography on florisil (6) and homogenized in $0.05 \mathrm{M}$ phosphate buffer. Human serum albumin obtained from the Commonwealth Serum Laboratory, Melbourne, as Cohn fraction V (recrystallized), extracted with $n$-heptane acidified to pH 3.2 with glacial acetic acid to remove preformed fatty acids, was added before homogenization. Final concentration of triolein was $25 \mu \mathrm{mol} /$ incubation with albumin concentration at $4 \%$. In the initial experiments no glucose, insulin, or cofactor lipoprotein was added. Triolein substrate was incubated with tissue homogenate at $\mathrm{pH} 7.4$ at a temperature of $37^{\circ}$ in an atmosphere of $95 \% \mathrm{O}_{2}-5 \% \mathrm{CO}_{2}$. Additions of either heparin (heparin injection BP $1000 \mu / \mathrm{ml}$; Boots Co. Ltd., Nottingham, England) or epinephrine (adrenalin injection 1:1000, Abbott Laboratories, Sydney, Australia) were made at timed intervals. In addition, tissue homogenate was incubated with phosphate buffer as a measure of release from endogenous triglyceride. The reaction was terminated by the addition of copper nitrate-triethanolamine reagent (27) followed by $2.0 \mathrm{ml}$ chloroform for the determination of free fatty acids as copper soaps by the method of Duncombe (9). Results were expressed as micromoles of FFA released from substrate triglyceride per $g$ tissue over $20 \mathrm{~min}$.

Levels of cAMP were determined in homogenates of tissue after epinephrine stimulation without added triglyceride. Aliquots of the incubation medium were precipitated with $6 \%$ trichloroacetic acid and the supernatant washed with watersaturated ethyl ether. The washed supernatant was dried under $\mathrm{N}_{2}$ and reconstituted in Tris-EDTA buffer. cAMP levels were measured using a competitive binding radioimmunoassay technique (Amersham Radiochemicals, The Radiochemical Centre, Amersham, Bucks, England). Results were expressed as picomoles of cAMP released per $g$ tissue.

Although in some tissue the release of glycerol to the incubation medium could be measured by an enzymic micromethod (18), the low endogenous triglyceride content of fetal tissue gave resulting glycerol levels at the limit of detection. To confirm lipolytic activity in the incubation, $1 \mu \mathrm{mol}$ [2(n)$\mathrm{H}^{3}$ ]glycerol trioleate (Amersham Radiochemicals) was added in a parallel experiment. The use of $\left[8-\mathrm{H}^{3}\right] \mathrm{cAMP}$ in the immunoassay of cAMP prevented the simultaneous use of [2(n)$\mathrm{H}^{3}$ ]glycerol trioleate. After extraction of the incubation medium with heptane, tritiated glycerol levels were determined in the aqueous phase.

\section{RESULTS}

Accumulation of triglyceride in the tissue with gestational age of the fetus is shown in Figure 1. Although the triglyceride content of the tissue is below that found in adipose tissue containing mature fat cells $(780-900 \mathrm{mg} / \mathrm{g})$, a substantial accumulation of tissue triglyceride starts at 16-17 weeks and increases through the ages studied.
Table 1 tabulates the increase in lipolytic activity of whole homogenates of fetal tissue induced by addition of either heparin or epinephrine. Release of FFA after addition of heparin was high in early gestation which is consistent with the higher proportion of capillary endothelium at this stage. After the addition of epinephrine $\left(10^{-4} \mathrm{M}\right)$ there is substantial release of FFA with all tissue homogenates.

The addition of epinephrine to the preparation in which no exogenous triglyceride substrate had been added, was associated with a rise in CAMP. Glycerol release was also detected at this time (Table 2). When radiolabeled triglyceride was added to the preparation, epinephrine again produced glycerol release, confirming lipolytic activity (Fig. 2). A dose relationship for cAMP production after epinephrine is present at each age studied (Fig. 3) but is more easily demonstrated in tissue taken at later gestation. Increases in basal cAMP production of 39,106 , and $170 \mathrm{pmol} / \mathrm{g} / 10 \mathrm{~min}$ for gestational ages 16,20 , and 22 weeks, respectively, seen when epinephrine is omitted, may be a function of tissue maturity.

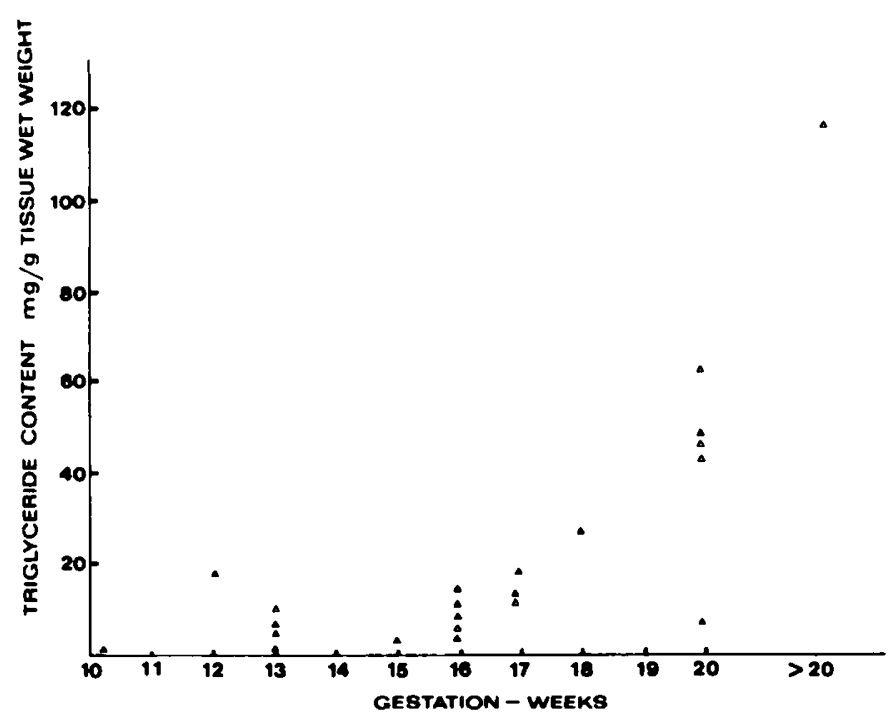

Fig. 1. Age-related changes in triglyceride content of fetal subcutaneous tissue.

Table 1. Release of FFA from 25 umol added triolein substrate by fetal tissue homogenates

FFA release, $\mu \mathrm{mol} / \mathrm{g}$ tissue $/ 20$ $\min ^{1}$

\begin{tabular}{lcc}
\cline { 2 - 3 } \multicolumn{1}{c}{ Gestational age of tissue } & $13-16$ weeks & $16-18$ weeks \\
\hline Basal & $0.8(.04)$ & $0.28(0.14)$ \\
Heparin added $(25 \mathrm{U})$ & $18.6(2.7)$ & $13.5(2.4)$ \\
Epinephrine added $\left(10^{-4} \mathrm{M}\right)$ & $14.4(4.4)$ & $27.2(5.5)$ \\
\hline
\end{tabular}

${ }^{1}$ Mean and SD of four duplicate measurements at each point shown.

Table 2. Glycerol and cAMP levels after epinephrine

\begin{tabular}{ccc}
\hline $\begin{array}{c}\text { Time after epinephrine } \\
\left(10^{-4} \mathrm{M}\right)^{1}\end{array}$ & $\begin{array}{c}\text { Glycerol, nmol/g tis- } \\
\text { sue wet wt }\end{array}$ & $\begin{array}{c}\text { cAMP, pmol/g tis- } \\
\text { sue wet wt }\end{array}$ \\
\hline 0 & 5.3 & 170 \\
$2 \mathrm{~min}$ & 11 & 445 \\
$5 \mathrm{~min}$ & 14 & 430 \\
$10 \mathrm{~min}$ & 24 & 350 \\
$20 \mathrm{~min}$ & 32 & 225 \\
\hline
\end{tabular}

1 Measurement of glycerol and cAMP was made after epinephrine stimulation $\left(10^{-4} \mathrm{M}\right)$ in fetal tissue homogenate $(40-60 \mathrm{mg})$ of 22 weeks of gestation. Triglyceride level of this tissue was estimated as $120 \mathrm{mg} / \mathrm{g}$ wet wt. Values are the mean of four observations at each time. 


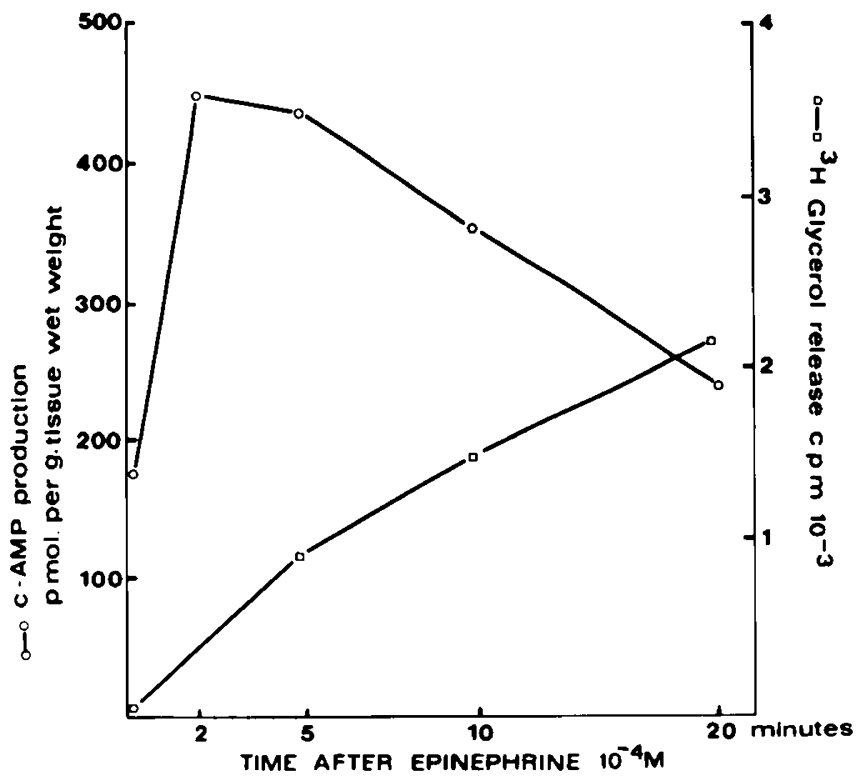

Fig. 2. cAMP production after epinephrine stimulation in fetal subcutaneous tissue homogenate $(40-60 \mathrm{mg}$ wet wt) taken at 22 weeks of gestation. Glycerol measurements obtained from separate incubations. Points shown are the means of four observations on a single tissue sample.

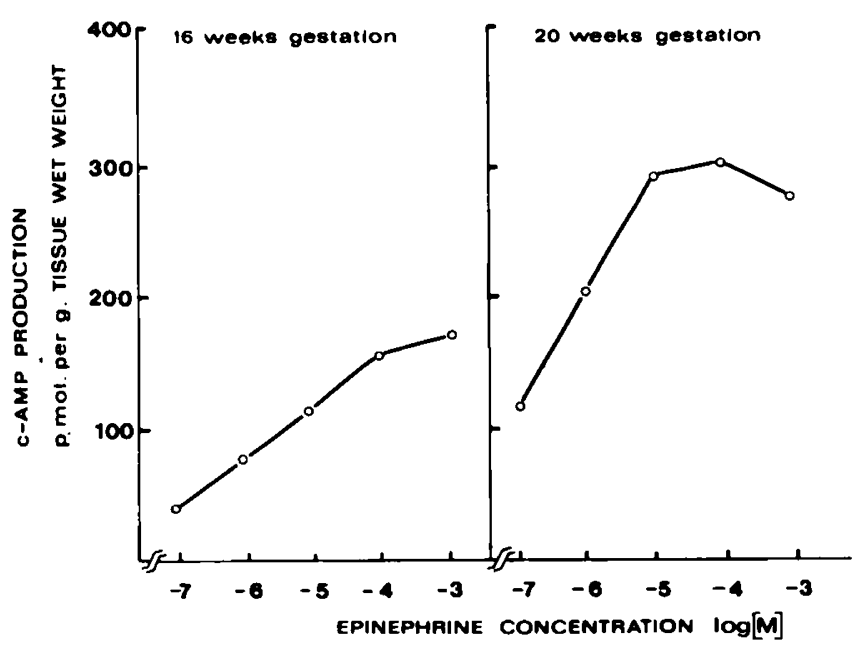

Fig. 3. Dose-response curve of epinephrine in fetal subcutaneous tissue. cAMP measured after incubation of fetal subcutaneous tissue (15 $\mathrm{mg}$ wet wt) with epinephrine $10^{-3}-10^{-7} \mathrm{M}$ at $37^{\circ}$ for $10 \mathrm{~min}$. Points shown are the mean for four observations on a single sample at each gestational age.

\section{DISCUSSION}

Most studies on the metabolism of mature adipose tissue have been made on isolated cell preparations in which cells are released from their connective tissue matrix after incubation with collagenase and separated by flotation (22). These cells have the metabolic features of intact tissue characterized by synthesis of triglyceride and by lipolytic activity. Lipogenesis is not unique to adipose tissue and may be demonstrated in a number of tissues including liver and intestinal mucosa (20). We believe, however, that demonstration of intracellular hormonedependent lipase activity is a specific characteristic of adipose cells and therefore may be used to identify them. cAMP acts as a common mediator for various hormones in mammalian tissues, and differentiation within the target cell determines the physiologic response. For an adipose cell the characteristic action of lipolytic hormones is the release of FFA and glycerol from stored triglyceride through activated triglyceride lipase (4). Activation of this lipase through the adenyl cyclase system has been demonstrated in mature adipose tissues of many mammalian species $(21,27)$.

It has been reported for rat adipose tissue that the ability of heparin to increase lipolytic activity in fat pad homogenates is due to increased activity in the stromal cells only (15). It was not possible to separate lipolytic activity of fetal cells from that of other components of fetal tissue in this homogenate, but the differential lipolytic responses to heparin and epinephrine implies that the tissue possesses the function of mature adipose tissue. Although in the adult, triglyceride lipase is most active during fasting, the activity of lipoprotein lipase is maximal in the fed state (15). When investigating fetal tissue, although the maternal nutritional status is assessed as fasting, the same metabolic condition cannot be assumed for the fetus. From this study, demonstration of triglyceride hydrolysis after the addition of heparin to fetal tissue suggests that lipoprotein triglyceride may be made available to the fetal cell.

Of greater importance is the demonstration of increase in medium cAMP levels after epinephrine stimulation. Epinephrine was used as an hormonal stimulus, for although both epinephrine and norepinephrine stimulate activity of adenyl cyclase (25), norepinephrine is specifically implicated in the response to cold exposure in developing animals (23). This specificity may introduce a limitation in studying the undefined tissue used in these studies. Similarly, isoproterol, a $\beta$-receptor stimulus, was not used. Glucagon has transient sensitivity in rat subcutaneous adipose tissue (13), but human adipose tissue has been reported to be unresponsive to glucagon (3). Changing levels in cAMP in fetal tissue with epinephrine suggests an activity similar to the mature adipose cell membrane.

These findings demonstrate a potential for this tissue. They do not necessarily indicate an in vivo process occurring at this period of development but rather show a functional ability of the cell. When considering this potential in a cell taken from a site where adult subcutaneous adipose deposition occurs, the definition of an adipose cell should not rely entirely on the presence of accumulated triglyceride. A study of the factors regulating triglyceride appearance in fetal subcutaneous tissue may determine critical times for hypercellularity in adipose tissue which precede those currently accepted.

\section{REFERENCES AND NOTES}

1. Boulton, T. J. C., Dunlop, M., and Court, J. M.: Adipocyte growth in the first 2 years of life. Aust. Paediat. J., 10: 301 (1974).

2. Brook, C. G. D.: Evidence for a sensitive period in adipose cell replication in man. Lancet, ii: 625 (1972).

3. Burns, T. W., and Langley, O.: Observations on lipolysis with isolated adipose tissue cells. J. Lab. Clin. Med., 72: 813 (1968).

4. Burns, T. W., and Langley, P. E.: Adrenergic receptors and cyclic AMP in the regulation of human adipose tissue lipolysis. Proc. Nat. Acad. Sci., 185: 115 (1971).

5. Butcher, R. W.: Cyclic 3'5'-AMP and the lipolytic effects of hormones on adipose tissue. Pharmacol. Rev., 18: 237 (1961).

6. Carroll, K. K.: Separation of lipid classes by chromatography on florisil. J. Lipid Res., 2: 135 (1961).

7. Cherkes, A., and Gordon, R. S.: The liberation of lipoprotein lipase by heparin from adipose tissue incubated in vitro. J. Lipid Res., 1: 97 (1959).

8. Chlouverakis, C.: Lipoprotein lipase activity in adipose, muscle and aortic tissue from rats of different age and in human subcutaneous adipose tissue. Proc. Soc. Exp. Biol. Med., 119: 775 (1965).

9. Duncombe, W. G.: The colorimetric determination of long chain fatty acids in the 0.05-0.5 $\mu$ mole range. Biochem. J., 83: 6 (1962)

10. Folch, J., Lees, M., and Sloane Stanley, G. H.: A simple method for the isolation and purification of total lipids from animal tissues. J. Biol. Chem., 226: 497 (1957).

11. Gilbert, C. H., and Galton, D. J.: The effect of catecholamines and fasting on cyclic-AMP and release of glycerol from human adipose tissue. Horm Metab. Res., 6: 299 (1974).

12. Goss, R. J.: Hypertrophy versus hyperplasia. Science, 153: 1615 (1966)

13. Hahn, P.: Response of brown and white adipose tissue to lipolytic agents in the rat during development. Pediat. Res., 5: 126 (1971).

14. Hirsch, J., and Knittle, J. L.: Cellularity of obese and non-obese human adipose tissue. Fed. Proc., 29: 1516 (1970).

15. Ho, S. J., Ho, R. J., and Meng, H. C.: Comparison of heparin-released and 
epinephrine sensitive lipases in rat adipose tissue. Amer. J. Physiol., 212(2): 284 (1967).

16. Khoo, J. C., and Steinberg, D.: Reversible protein kinase activation of hormone-sensitive lipase from chicken adipose tissue. J. Lipid Res., 15: 602 (1974).

17. Kupiecki, F. P.: Partial purification of monoglyceride lipase from adipose tissue. J. Lipid Res., 7: 230 (1966).

18. Laurell, S., and Tibbling, G.: An enzymic fluorometric micromethod for the determination of glycerol. Clin. Chim. Acta, 13: 317 (1966).

19. Persson, B., Bjorntorp, P., and Hood, B.: Lipoprotein lipase activity in human adipose tissue: Conditions for release and relationship to triglyceride in serum. Metabolism, 15: 730 (1966).

20. Polheim, D., David, J. S. K., Schultz, F. M., Wylie, M. B., and Johnson, J. $M$.: Regulation of triglyceride biosynthesis in adipose and intestinal tissue. J. Lipid Res., 14: 415 (1973)

21. Rizack, M. A.: Epinephrine-sensitive lipolytic activity in adipose tissue. J. Biol. Chem., 236: 657 (1961).

22. Rodbell, M.: Metabolism of isolated fat cells: Effect of hormones on glucose metabolism and lipolysis. J. Biol. Chem., 239: 375 (1964)

23. Scopes, J. W., and Tizzard, J. P. M.: The effects of intravenous nor-adrenalin

Copyright (C) 1978 International Pediatric Research Foundation, Inc. $0031-3997 / 78 / 1204-0279 \$ 02.00 / 0$ on the oxygen consumption of newborn mammals. J. Physiol., 165: 305 (1963).

24. Scow, R. O., Hamosch, M., Blanchette-Mackie, E. J., and Evans, A. J.: Uptake of blood triglyceride by various tissues. Lipids, 7: 497 (1973).

25. Sutherland, E. W., and Robinson, G. A.: The role of cyclic 3'5'-AMP in response to catecholamines and other hormones. Pharmacol. Rev., 18: 145 (1966).

26. Van Handel, E., and Zilversmit, D. B.: Micromethod for the direct determination of serum triglycerides. J. Lab. Clin. Med., 50: 152 (1975).

27. Vaughn, M., Berger, J. F., and Steinberg. D.: Hormone-sensitive lipase and monoglyceride lipase activity in adipose tissue. J. Biol. Chem., 239: 401 (1964).

28. We thank Ms. Mary Reddan for her assistance in preparation of the manuscript.

29. Requests for reprints should be addressed to: J. M. Court, M.D., Department of Paediatrics, University of Melbourne, Royal Children's Hospital, Parkville, Victoria 3052 (Australia).

30. Received for publication March 28, 1977

31. Accepted for publication July 27, 1977 